\title{
Effect of Inoculum Concentration and Pretreatment on Biomethane Recovery From Cotton Gin Trash
}

\author{
Harjinder Kaur $^{1} \&$ Raghava R. Kommalapati ${ }^{1,2}$ \\ ${ }^{1}$ Center for Energy and Environmental Sustainability, Prairie View A\&M University, Prairie View, TX USA \\ ${ }^{2}$ Department of Civil and Environmental Engineering, Prairie View A\&M University, Prairie View, TX USA \\ Correspondence: Raghava R. Kommalapati, Center for Energy and Environmental Sustainability, Department of \\ Civil and Environmental Engineering, Prairie View A\&M University, 700 University Drive, Prairie View, TX \\ 77446, USA. Tel: 1-936-261-1660. E-mail: rrkommalapati@pvamu.edu
}

Received: January 13, 2021

Accepted: February 21, 2021

Online Published: March 15, 2021

doi:10.5539/jas.v13n4p15

URL: https://doi.org/10.5539/jas.v13n4p15

This research is supported by the USDA-CBG program grant (Award No. 2018-38821-27750) and partial support by the NSF CREST Center for Energy and Environmental Sustainability (CEES) at Prairie View A\&M University (NSF Award \#1914692), Prairie View, Texas.

\begin{abstract}
The potential of cotton gin waste, a considerable challenge to the gin owners, has not been fully investigated as a renewable energy source via anaerobic digestion. The weathered cotton gin trash and inoculum for triplicate biomethane potential assays were obtained from a local cotton gin mill and a municipal wastewater treatment plant, respectively. The moisture, total solids, volatile solids, and C, H, N, S, hemicellulose + cellulose, and lignin contents of gin waste were determined in triplicates. The biomethane potential of untreated and pretreated (hot water and $6 \% \mathrm{NaOH}$ (wet CGT weight basis) gin waste was determined at different inoculum to substrate ratios. The highest cumulative biomethane yield of $111.8 \mathrm{~mL} \mathrm{~g}_{\mathrm{vs}}{ }^{-1}$ was observed in inoculum to substrate ratio of 2.3 , and it was statistically similar to the values; $101.8,104.7,100.5$, and $108.9 \mathrm{~g}_{\mathrm{vs}}{ }^{-1}$, observed in $0.8,1.2,1.5$, and 1.9, respectively. The biomethane yield at the inoculum to substrate ratio of 0.4 was significantly lower than all higher ratios. The $\mathrm{T}_{80-90}$ for biomethane production was $26-30$ for the ISRs of 1.2, 1.5, and 2.3. The $\mathrm{T}_{80-90}$ for inoculum to substrate ratios of $0.4,0.8$, and 1.9 were $26-31,27-32$, and 27-31 d, respectively. The modified Gompertz equation fitted very well $\left(\mathrm{R}^{2}=0.98-0.99\right)$ to the anaerobic digestion at all inoculum to substrate ratios and pretreatments as the observed and predicted biomethane values were similar. The model predicted a lag phase of 8-10 days for control and treatments compared to the observed of 10-15 days. The highest biodegradability of $24.8 \pm 2.6 \%$ was observed at inoculum to substrate ratio of 2.3 , which was statistically similar to the values observed in ratios of $0.8,1.2,1.5$, and 1.9, respectively. Among pretreatments, the highest biodegradability of $33.0 \pm 2.4$ was observed in $6 \% \mathrm{NaOH}$ pretreatment, and it was statistically similar to hot water treatment and non-pretreated or control. These research findings advance the knowledge in the anaerobic degradation of cotton gin trash, thus helping to maximize biomethane recovery from this agro-industrial waste.
\end{abstract}

Keywords: anaerobic digestion, inoculum to substrate ratio, biomethane potential assays, kinetic modeling, pretreatment

\section{Introduction}

Cotton is one of the world's most important cultivated crops owing to its high-quality natural fiber. According to a recent statistical report, around 26.7 million metric tons of cotton were produced globally during the 2019-20 growing season, and the United States was the major exporter (Cotton Incorporated, 2020). Texas is a major cotton-producing state in the US; other US states producing cotton are Georgia, Arkansas, and Mississippi (Figures 1 and 2). The upland cotton (Gossypium hirsutum) is dominant throughout Texas. Pima cotton (G. barbadense), which is well adapted to the desert, is grown in far western Texas. 


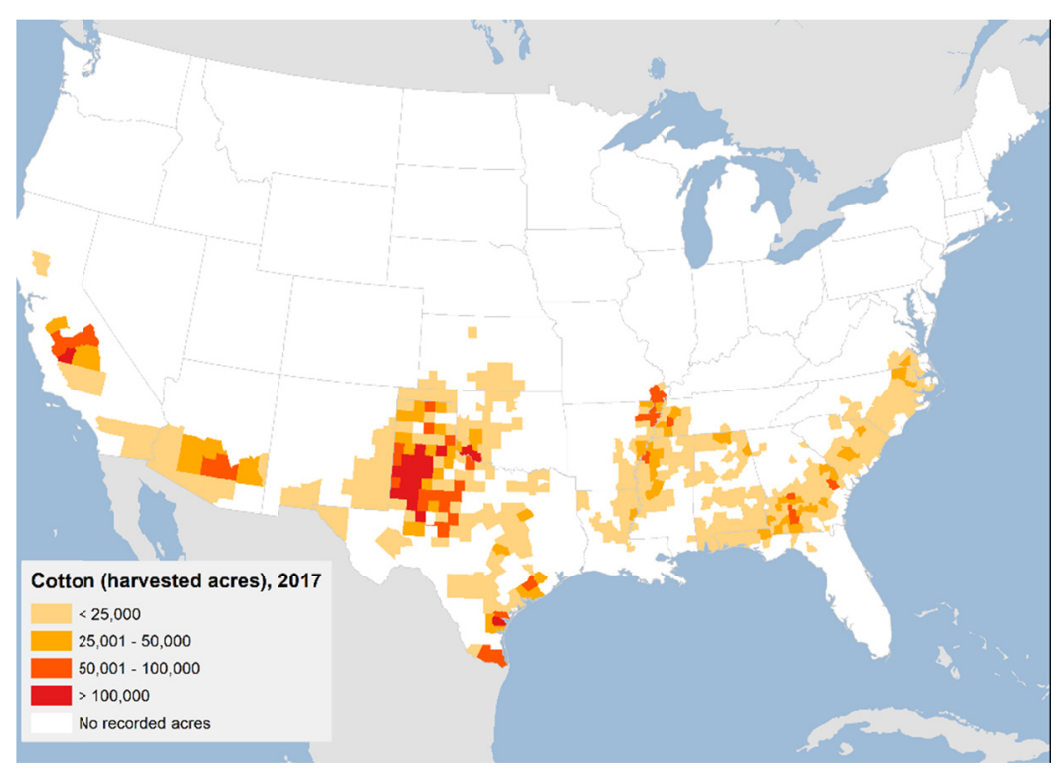

Figure 1. Cotton harvested acres, 2019

Source; USDA.

Once picked from the farm, cotton is further processed in gins to separate fiber, leaving behind cotton gin trash (CGT) as agro-industrial waste. According to Thomasson (1990), ginning one bale of cotton yields about 37-147 $\mathrm{Kg}$ of CGT, thus annually generating millions of tons of CGT in major cotton growing US states (Figures 1 and 2 ). The composition and amount of CGT generated depend upon the cotton cultivar and harvest method (Agblevor, 2006; Thomasson, 1990). In the US, cotton is mechanically harvested, and it is mainly composed of clean lint (8-15\%), hulls (18.5-32.9), stem (5.2-5.9), grass (0.1-1.1), seed (0-2.9\%), motes (20.4-21.6\%), small leaves (19.4-34.9\%) (Agblevor, 2003). The traditional management strategies have been to use it for feeding and bedding for the animals or composting, followed by addition to the soil as humus. The presence of microbial pests (verticillium wilt in particular) and pesticide residues, low heating value (Holt, 2006) in energy production limit the recycling options of CGT (Hamawand et al., 2016; Haque et al., 2020). The proper disposal of CGT is a challenge for the gin mills; thus, the gin mill owners spend money on disposing of CGT (Thomasson, 1990; Hamawand et al., 2016). The other potential uses of CGT include as a source of micro and nanocrystalline cellulose, dye absorbent in wastewater treatment, and a component of transparent plastics (Haque et al., 2020).

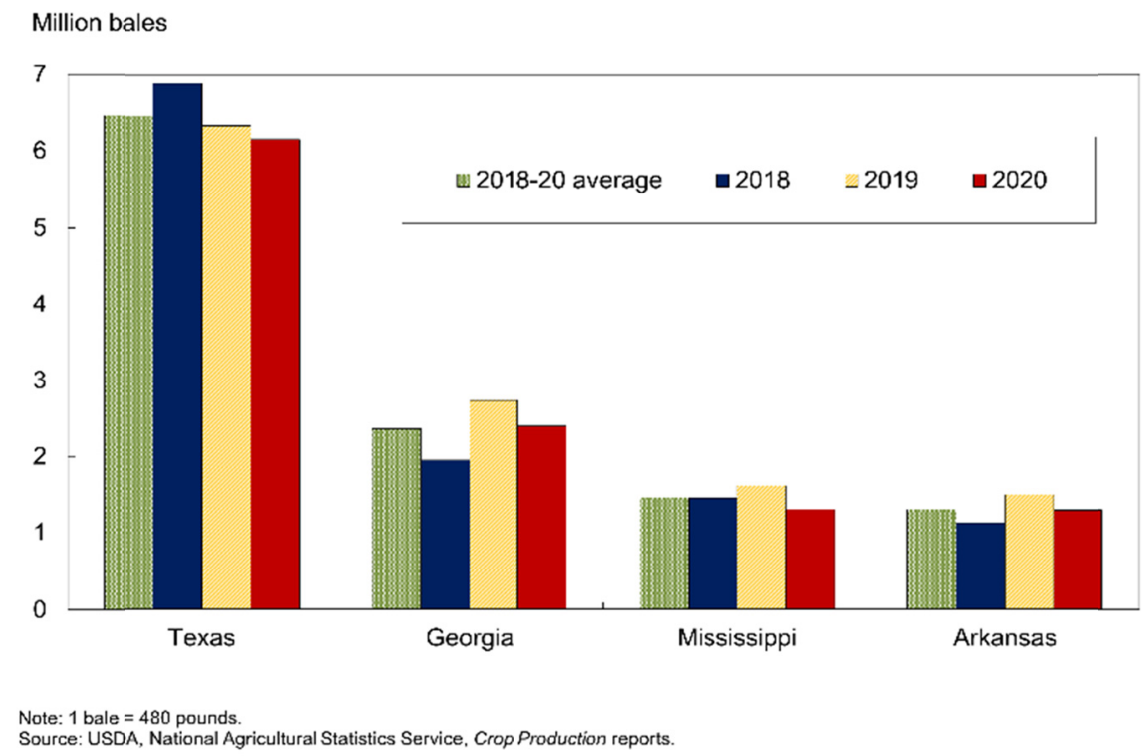

Figure 2. Leading US cotton-producing states, 2018-2020 
However, the urgency to lower fossil fuel consumption had the scientists investigating agro-industrial wastes such as CGT as potential renewable energy sources (Zabaniotou et al., 2010). Consequently, CGT has been investigated as a bioenergy source through ethanol production, gasification, and anaerobic degradation (Hamawand et al., 2016). The high chemical oxygen demand (COD) and volatile solid (VS) contents in CGT can be recovered as biomethane through anaerobic degradation (Hamawand et al., 2016; Wilde et al., 2010).

Anaerobic degradation is widely adopted to convert organic matter into biomethane (USEPA, 2019; Guo et al., 2015). According to the United States Environmental Protection Agency (USEPA), as of October 2019, 287 anaerobic digesters were operating at the animal farms across the nation (USEPA, 2019). They were adopted by the farmers to curb methane emissions from animal farms (manures) as directed by EPA under the regulation of the National Pollutant Discharge Elimination System (USEPA, 2019). Biomethane potential (BMP) assays are used to determine a given substrate's suitability for anaerobic digestion. Anaerobic digestion relies upon the intricate balance of various bacterial groups which carry out the four distinct phases of hydrolysis (substrate break down to simple organic and amino acids), acidogenesis (conversion of simple organic and amino acids to volatile fatty acids, $\mathrm{H}_{2}$ and $\mathrm{CO}_{2}$ ), acetogenesis (volatile fatty acids are converted to $\mathrm{CH}_{3} \mathrm{COOH}$ ) and finally methanogenesis (Meegoda et al., 2018). The microbial degradation is impacted by inoculum, substrate, experimental and operational conditions (Raposo et al., 2011). Some of the most important factors impacting the process; hence biomethane yield are inoculum to substrate ratio or ISR and substrate composition (Ntiamoah-Ohemeng \& Datta, 2019; Raposo et al., 2011).

There are some studies (Cheng \& Zhong, 2014; Adl et al., 2012; Isci \& Demirer, 2007; Funk et al., 2005) that focused on the BMP and/or ISR of cotton wastes in mono-digestion or co-digestion with manures. Adl et al. (2012) determined the effects of pretreatment, inoculum source, and feed to inoculum ratio (F/I) on the BMP of cotton stalks. Cheng and Zhong (2014) investigated the effects of the F/I, pretreatment, and co-digestion (with swine manure) on the BMP of cotton stalks. Additionally, the authors fitted the modified Gompertz equation to the cumulative experimental data and reported a high correlation between experimental and predicted values. Funk et al. (2005) co-digested CGT with swine manure (the mixing ratios from 1:1-10:1) in a two-stage bioreactor. Isci and Demirer (2007) reported that the addition of basal media yields higher biomethane during the anaerobic digestion of cotton oil cake, seed hull, and stalks.

Once the particle size and crystallinity of the biomass are reduced via mechanical milling, several pretreatment methods are available to remove the lignin fraction of the biomass, as summarized by Hassan et al. (2018). Two of these methods are hot water and alkaline treatments, which remove soluble and whole lignin and hemicellulose fractions, respectively (Hassan et al., 2018). The effect of these pretreatments on BMP of CGT still has not been investigated.

The biomethane potential assays were conducted at different inoculum to substrate ratios utilizing untreated and pretreated (hot water and alkali) cotton gin trash as feedstock. The digester performance at each treatment was evaluated by simulating the process with mainstream mathematical models and comparing them with theoretical values.

\section{Method}

\subsection{Substrate and Inoculum}

The aged CGT (from more than 3 months cotton ginning, Figure 3) was collected from Varisco-Court Gin Co. (5354 Steel Store Rd, Bryan, TX, 77807). The samples were collected from weathered, transition, and core layers and mixed to obtain a uniform gin waste. It was passed through Willy mill, sieved (2 $\mathrm{mm})$ to obtain small particles, and stored at $4{ }^{\circ} \mathrm{C}$ in the refrigerator. 


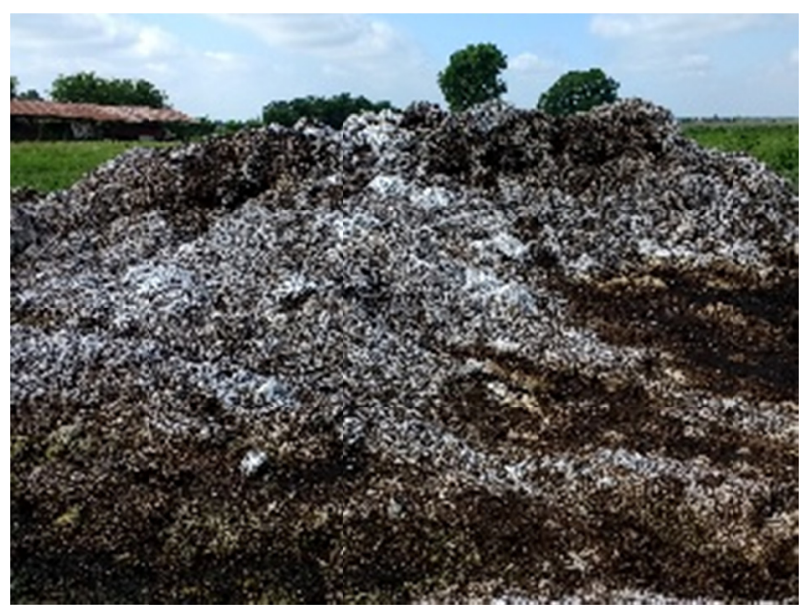

Figure 3. Cotton gin trash

The fresh inoculum obtained from the Prairie View wastewater treatment plant (operating at mesophilic temperature) was de-gassed (Holliger et al., 2016; Angelidaki et al., 2009) for a week and stored at $4{ }^{\circ} \mathrm{C}$. The well-mixed samples of CGT and inoculum in triplicates were characterized for VS per method 2540 (APHA, 2005) using a Lindberg Blue M Electric furnace (Fisher Scientific, Pittsburgh, PA). The elemental composition $(\mathrm{C}, \mathrm{H}, \mathrm{N}$, and $\mathrm{S}$ ) of the CGT was determined with the Flash 2000 elemental analyzer (Elementar Americas Inc., Ronkonkoma, NY). The lignin, cellulose, and hemicellulose contents were determined by thermogravimetric analysis in the Perkin Elmer Diamond TG/DTG system.

\subsection{Biomethane Potential Assays}

\subsubsection{Effect of Inoculum to Substrate Ratio}

The effect of ISR on the biomethane recovery from the CGT during anaerobic degradation was determined by running BMP assays in $250 \mathrm{~mL}$ serum bottles (Fisher Scientific, Pittsburgh, PA). Of the twenty-one bioreactors, each containing $1.3 \mathrm{~g}$ CGT $\left(1.0 \mathrm{~g}_{\mathrm{vs}}\right)$, the control bioreactors did not receive inoculum (0 ISR). The rest of them received varying amounts of inoculum $(0.5,1.0,1.5,2.0,2.5$ and $5 \mathrm{~mL})$ to obtain ISRs of $0.4,0.8,1.2,1.5,1.9$ and 2.3, respectively. Blank bioreactors contained all ingredients except CGT. An equal volume of trace medium (Moody et al., 2009) was added to each bioreactor. The working volume of $100 \mathrm{~mL}$ in each bioreactor was achieved by adding deionized water. At day zero, the contents of each bioreactor were analyzed for $\mathrm{pH}$, which varied between 6.5 and 7.8, which is in the optimum range (Filer et al., 2019) at the start of the assays. The bioreactors were purged with $\mathrm{N}_{2}$ gas $(99.9 \%$ purity) for five minutes and sealed with straight plug stoppers, and secured using aluminum crimp seals (Fisher Scientific, Pittsburgh, PA) for biomethane sampling and maintaining the anaerobic conditions, respectively. The bioreactors were incubated at $36 \pm 1{ }^{\circ} \mathrm{C}$, and biomethane was measured (liquid displacement method, by using alkaline water, $\mathrm{pH} 10.30$ ) daily. The daily gas measurements were continued until the total biomethane production during three consecutive days was less than $1 \%$ of the previously accumulated biomethane (Holliger et al., 2016).

\subsubsection{Effect of Pretreatments}

The effect of hot water and alkali pretreatments on the BMP of CGT was determined as described by Adl et al. (2012) and Pang et al. (2008), respectively. Triplicates of $\left.10 \mathrm{~g} \mathrm{CGT} \mathrm{(7.9} \mathrm{g}_{\mathrm{vs}}\right)$ were subjected to thermal or $0.6 \%$ $\mathrm{NaOH}$ in $250 \mathrm{~mL}$ serum bottles. Briefly, $50 \mathrm{~mL}$ DI water was added to all serum bottles. For thermal treatment, serum bottles were sealed using plastic caps and aluminum cramps and placed in a water bath. The temperature was gradually raised to $100{ }^{\circ} \mathrm{C}$ and maintained for $15 \mathrm{~min}$. The serum bottles were brought to room temperature before the addition of the remaining ingredients.

For alkali treatment, $0.6 \mathrm{~g}$ or $6 \% \mathrm{NaOH}$ (CGT wet weight basis) was directly added to each of the bottles. Triplicate blanks received all ingredients except CGT. The BMP assays were run with an ISR of 2. Other experimental conditions were the same as described in section 2.2.1.

\subsection{Theoretical Maximum Biomethane Yield}

The theoretical maximum biomethane yield $\left(451.0 \mathrm{~mL} \mathrm{~g}_{\mathrm{vs}}{ }^{-1}\right)$ was determined by Buswell's equation (Buswell \& Neave, 1930) below as described by Raposo et al. (2011) from the empirical formula of CGT $\left(\mathrm{C}_{390.0} \mathrm{H}_{450.0} \mathrm{O}_{290.8} \mathrm{~N}_{21.2} \mathrm{~S}_{0.6}\right)$ using the results of elemental analysis (Table 1). 


$$
\mathrm{TMY}=\frac{22400 \times\left[\left(\frac{\mathrm{a}}{2}\right)+\left(\frac{\mathrm{b}}{8}\right)-\left(\frac{\mathrm{c}}{4}\right)-\left(\frac{3 \mathrm{~d}}{8}\right)-\left(\frac{\mathrm{e}}{4}\right)\right]}{12 \mathrm{a}+\mathrm{b}+16 \mathrm{c}+14 \mathrm{~d}+32 \mathrm{e}}
$$

Where, $\mathrm{a}=390.0, \mathrm{~b}=450.0, \mathrm{c}=290.8, \mathrm{~d}=21.2, \mathrm{e}=0.6$.

\subsection{Biodegradability}

The biodegradability (BD) of a substrate is its fraction that is converted to biomethane during anaerobic digestion. The BD of CGT was determined using cumulative biomethane yield (EBY) from the experimental and theoretical biomethane (EMY and TBY) as described by Raposo et al. (2011).

$$
\mathrm{BD}(\%)=\frac{\mathrm{EBY}}{\mathrm{TBY}} \times 100
$$

\subsection{Biomethane Production Kinetics}

The anaerobic degradation process or bacterial growth in the bioreactors can be described by fitting the modified Gompertz equation developed by Lay et al. $(1996,1997)$ as described below:

$$
\mathrm{P}(\mathrm{t})=\mathrm{P}_{0} \times \exp \left\{-\exp \left[\frac{\mathrm{R}_{\mathrm{m}} \cdot \mathrm{e}}{\mathrm{P}_{0}}(\lambda-\mathrm{t})+1\right]\right\}
$$

Where, $\mathrm{P}(\mathrm{t})=$ The cumulated methane $\left(\mathrm{mL} \mathrm{g}_{\mathrm{vs}}{ }^{-1}\right.$, minus the blank) at digestion time $\mathrm{t}$ (days); $\mathrm{P}_{0}=\mathrm{Maximum}$ cumulative methane production $\left(\mathrm{mL} \mathrm{g}_{\mathrm{vs}}{ }^{-1}\right) ; \mathrm{R}_{\mathrm{m}}=$ Maximum daily rate of biomethane production $\left(\mathrm{mL}_{\mathrm{vs}}{ }^{-1} \mathrm{~d}^{-1}\right) ; \lambda$ $=$ lag phase (days), minimum time to produce biomethane; $\mathrm{e}=$ Mathematical constant 2.718 .

\subsection{Data Analysis}

The experimental data were processed in Microsoft Excel 2010 (Microsoft, USA). The biomethane volume was converted to dry gas volume at STP by multiplying with a dry biomethane factor of 0.838 as described by Richards et al. (1991). The blank value was subtracted from the treatment values. All of the data were analyzed using the general linear model (GLM) and analysis of variance procedure of Statistical Analysis System (SAS ${ }^{\circledR}$ 9.2, SAS Institute Inc., Cary, NC, USA), and statistically significant treatment means were separated using the least significant difference (LSD) test at 5\% probability.

\section{Results and Discussion}

\subsection{Cotton Gin Trash Composition}

Carbohydrates (hemicellulose + cellulose) were $56 \%$, while lignin or acid-insoluble fraction was found to be $32.7 \%$ (Table 1).

Table 1. Cotton gin trash and inoculum characterization

\begin{tabular}{lll}
\hline Parameter (\%) & Inoculum & CGT \\
\hline Moisture & $97.2 \pm 0.3$ & $12.3 \pm 0.4$ \\
TS & $2.8 \pm 0.3$ & $87.7 \pm 0.4$ \\
VS & $1.5 \pm 0$ & $78.9 \pm 0.8$ \\
Ash & $1.5 \pm 0.4$ & $8.8 \pm 0.6$ \\
N & - & $1.3 \pm 0$ \\
C & - & $47.3 \pm 1.2$ \\
H & - & $4.5 \pm 0$ \\
S & - & $0.2 \pm 0$ \\
O & - & $46.6 \pm 1.5$ \\
C/N & - & $36.3 \pm 0.9$ \\
Cellulose + Hemi-cellulose & - & 56.0 \\
Lignin & - & 32.7 \\
\hline
\end{tabular}

Note. All values, except moisture, TS, VS, and ash are mean \pm SD from triplicate percentages of total sample dry weight basis (w/w).

Agblevor et al. (2006) reported 11.2, 37.1, and 21.7 to $27 \%$ ash, total carbohydrates, and acid-insoluble fractions in CGT collected from gin mills in the US. The CGT was collected from a pile that had been stored in the open in a local gin mill for 3 months. 
The open storage of the CGT alters the composition of the biomass, lowering the total carbohydrate content (Agblevor, 2006). Although, the CGT for this study was collected from an outdoor storage pile, the carbohydrate content was similar to the fresh sample utilized by Jeoh and Agblevor (2000). The percentage of C, H, N, and S was $47.3,4.5,1.3$, and 0.2 , respectively. The value for oxygen was determined by subtracting the total sum of percent values of $\mathrm{C}, \mathrm{H}, \mathrm{N}$, and $\mathrm{S}$ from 100 . The observed $\mathrm{C} / \mathrm{N}$ ratio of CGT; $36.3 \pm 0.9$; is in the range of 28.0-51.3 in previous studies (Hamawand et al., 2016; Santos et al., 2016; Majglinao et al., 2015).

\subsection{Daily Biomethane Yield}

There was no effect of ISR on the total volume of biomethane on day one after incubation. On day 2, the bioreactors with inoculum had significantly higher biomethane volume as compared to the control (Figures 4 and 5). The peak volumes were observed between days 13-17. For 0 ISR, maximum biomethane of $1.5 \mathrm{~mL} \mathrm{gvs}^{-1} \mathrm{was}^{2}$ observed on day 3 and stopped on day 14. For ISRs $0.4,0.8,1.9$, and 2.3, the maximum daily biomethane volumes of $15.5,14.7,18.2$, and $16.3 \mathrm{~mL} \mathrm{~g}_{\mathrm{vs}}{ }^{-1}$, respectively, were observed on day 16 . The biomethane volume from ISR 1.2 peaked at two consecutive days (16 and 17) at 13.3 and $13.4 \mathrm{~mL} \mathrm{gvs}^{-1}$. Similarly, two peaks of daily biomethane volumes of 13.5 and $15.5 \mathrm{~mL} \mathrm{~g}_{\mathrm{vs}}^{-1}$ were observed on days 13 and 19 for ISR of 1.5 .

In CGT pretreatment assay, up to $12 \mathrm{~d}$, lower daily biomethane values were observed in $6 \% \mathrm{NaOH}$ than hot water and control. However, alkali-treated CGT consistently yielded higher biomethane from 13 to $27 \mathrm{~d}$.

\subsection{Cumulative Biomethane}

From the cumulative biomethane chart (Figures 4 and 5), it was observed that without inoculum, CGT was not anaerobically degradable. For all ISRs, there was a lag phase of 10 days, indicating hydrolysis as the rate-limiting factor and time for microbial acclimation to the substrate. Isci and Demirer (2007) also reported a lag phase of 5-10 days in BMP assays involving cotton stalks, as the inoculum was not acclimated to the substrate. The cumulative biomethane volume at the end of the BMP assays increased with an increase in the ISR.
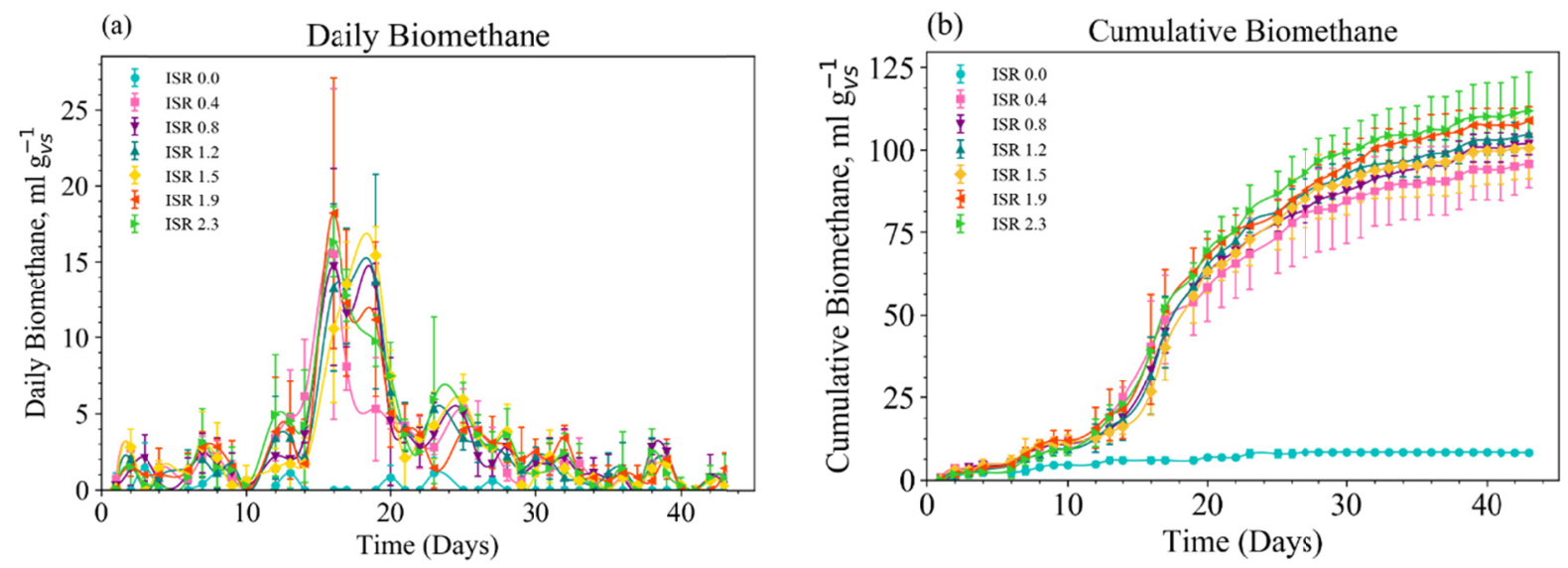

Figure 4. Daily (a) and cumulative (b) biomethane yields $\left(\mathrm{mL} \mathrm{gvs}^{-1}\right)$ from cotton gin trash at different inoculum to substrate ratios (ISRs)

Note. The error bars represent the standard deviation. Each dot on the chart represents the mean of three values. 

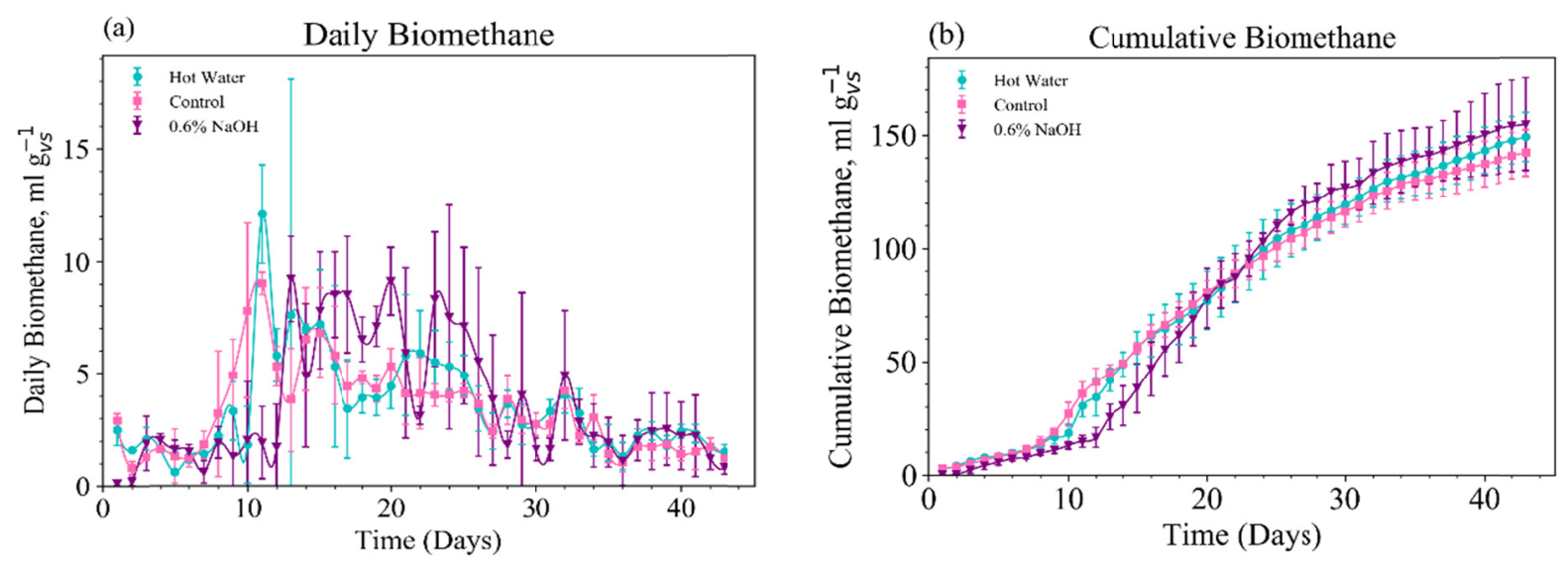

Figure 5. Daily (a) and cumulative (b) biomethane $\left(\mathrm{mL} \mathrm{g}_{\mathrm{vs}}{ }^{-1}\right)$. from control (CGT), hot water, and $6 \% \mathrm{NaOH}$ pretreatments

Note. The error bars represent the standard deviation. Each dot on the chart represents the mean of three values.

The biomethane recovered at the ISRs of 0.8.1.2, 1.5, 1.9, and 2.3 was similar $(\mathrm{P}<0.0001)$. The cumulative biomethane measured from the control bioreactors was significantly $(\mathrm{P}<0.0001)$ lower than all other treatments. At 0.4 ISR, the recovered biomethane was significantly $(\mathrm{P}<0.0001)$ lower than all other ISRs (except 0 ISR). The low ISR may have caused biomethane inhibition due to the accumulation of volatile fatty acids (Angelidaki \& Sanders, 2004). The technical digestion time $\left(\mathrm{T}_{80-90}\right)$ for biomethane production (the time taken to produce $80-90 \%$ of the cumulative biomethane) for the ISRs of 1.21 .5 and 2.3 was found to be $26-30$, whereas the $\mathrm{T}_{80-90}$ for the ISRs of 0.4, 0.8 and 1.9 varied between 26-31, 27-32, and 27-31 days. The control yielded $80-90 \%$ of the biomethane between 20-23 days. Kafle et al. (2013) stated that $\mathrm{T}_{80-90}$ could be used as hydraulic retention time (HRT) for the continuous anaerobic digestion of substrates. Adl et al. (2012) reported that the biomethane recovery from cotton stalks increased with an increase in ISR. Cheng and Zhong (2014) also reported that the biomethane yield from cotton stalks increased with an increase in ISR. They reported a biomethane yield of $113-180 \mathrm{~mL} \mathrm{~g}_{\mathrm{vs}}{ }^{-1}$ for the $\mathrm{F} / \mathrm{I}$ (feed to inoculum ratio, VS basis) of 6-2. We observed cumulative biomethane in the range of 95.8-111.8 $\mathrm{mL} \mathrm{g}_{\mathrm{vs}}^{-1}$ for 0-2.3 ISRs (Table 2). Isci and Demirer (2007) reported a biomethane yield of $61.5 \mathrm{~mL} \mathrm{~g}_{\mathrm{vs}}{ }^{-1}$ for cotton stalks. The effect of ISR on the BMP of CGT has not been reported so far. Our findings corroborate with the observations by Ohemeng-Ntiamoah \& Datta (2019) that ISR in BMP assays should be $\leq 2$, but $\leq 1$ should be avoided.

\subsection{Biomethane Production Kinetics}

The principal kinetic parameters of biomethane recovery from CGT during the anaerobic digestion were determined by employing the modified Gompertz model (Figures 6 and 7, Table 2). The model is most suitable for the growth curves with a prolonged lag phase as observed by the experimental daily biomethane yields (Figure 1). The simulated maximum biomethane yield was similar $(\mathrm{P}<0.0001)$ to the experimental cumulative yields in both experiments. The maximum daily rate of biomethane production $\left(\mathrm{R}_{\mathrm{m}}\right)$ was significantly $(\mathrm{P}<$ 0.0001 ) lower in ISR 0.4 than all other ISRs. The $R_{m}$ for all other ISRs was similar. The $\lambda$ among ISRs varied between $8.2 \pm 0.5$ and $10.3 \pm 0.7 \mathrm{~d}$. In this study, the inoculum was collected from a municipal wastewater treatment plant, while the substrate was a lignocellulosic agro-industrial waste. Hence, the high lag phase may be attributed to the microbial acclimation to the new substrate (Kythreotou et al., 2014).

Among control, hot water, and alkali pretreatments, the prolonged lag phase of $9.8 \pm 1.0 \mathrm{~d}$ was observed in $6 \%$ $\mathrm{NaOH}$, which corroborates with the observed daily values. In control and hot water treated CGT, the lag phase was $5.1 \pm 1.0$ and $6.0 \pm 0.7$, respectively. The high correlation coefficient (0.97-0.99) further supported that the equation is well fitted to the anaerobic digestion of CGT at all ISRs except control (0 ISR) and pretreatments. Cheng and Zhong (2014) also reported that the modified Gompertz equation fitted well to the anaerobic degradation of cotton stalks. 
Table 2. Gompertz parameters, experimental biomethane, and biodegradability (BD) at different inoculum to substrate ratios (ISRs) and pretreatments

\begin{tabular}{|c|c|c|c|c|c|c|}
\hline Treatment & $\mathrm{P}^{1}$ & $\mathrm{E}^{2}$ & $\mathrm{R}_{\mathrm{m}}{ }^{3}$ & $\lambda^{4}$ & $\mathrm{R}^{2}$ & $\mathrm{BD}(\%)$ \\
\hline \multicolumn{7}{|l|}{ ISR Effect } \\
\hline 0 ISR & $8.7 \pm 0.3 \mathrm{c}$ & $8.4 \pm 0.3 \mathrm{c}$ & $0.4 \pm 0.1 \mathrm{c}$ & $-1.1 \pm 1.6 \mathrm{c}$ & $0.977 \pm 0 \mathrm{~b}$ & $1.8 \pm 0.1 \mathrm{c}$ \\
\hline 0.4 ISR & $96.6 \pm 6.6 \mathrm{~b}$ & $95.8 \pm 7.2 \mathrm{~b}$ & $5.0 \pm 1.2 \mathrm{~b}$ & $8.2 \pm 0.5 \mathrm{~b}$ & $0.996 \pm 0 \mathrm{a}$ & $21.2 \pm 1.6 \mathrm{~b}$ \\
\hline 0.8 ISR & $101.8 \pm 4.6 \mathrm{ab}$ & $101.8 \pm 3.2 \mathrm{ab}$ & $5.5 \pm 0.6 \mathrm{ab}$ & $9.2 \pm 0.8 \mathrm{ab}$ & $0.993 \pm 0 \mathrm{a}$ & $22.6 \pm 0.7 \mathrm{ab}$ \\
\hline 1.2 ISR & $103.3 \pm 4.9 \mathrm{ab}$ & $104.7 \pm 4.6 \mathrm{ab}$ & $6.3 \pm 0.2 \mathrm{a}$ & $10.2 \pm 1.3 \mathrm{ab}$ & $0.995 \pm 0 \mathrm{a}$ & $23.2 \pm 1.0 \mathrm{ab}$ \\
\hline 1.5 ISR & $101.4 \pm 9.8 \mathrm{ab}$ & $100.5 \pm 9.3 \mathrm{ab}$ & $6.1 \pm 0.7 \mathrm{ab}$ & $10.3 \pm 0.7 \mathrm{a}$ & $0.992 \pm 0 \mathrm{a}$ & $22.2 \pm 2.1 \mathrm{ab}$ \\
\hline 1.9 ISR & $109.7 \pm 7.5 \mathrm{a}$ & $108.9 \pm 4.2 \mathrm{a}$ & $5.7 \pm 0.4 \mathrm{ab}$ & $8.8 \pm 1.9 \mathrm{ab}$ & $0.995 \pm 0 \mathrm{a}$ & $24.1 \pm 0.9 \mathrm{a}$ \\
\hline $2.3 \mathrm{ISR}$ & $111.6 \pm 10.6 \mathrm{a}$ & $111.8 \pm 11.7 \mathrm{a}$ & $6.6 \pm 0.3 \mathrm{a}$ & $9.7 \pm 0.5 \mathrm{ab}$ & $0.994 \pm 0 \mathrm{a}$ & $24.8 \pm 2.6 \mathrm{a}$ \\
\hline $\mathrm{LSD}^{5}$ & 12.3 & 12.0 & 1.2 & 2.1 & 0.01 & 2.8 \\
\hline \multicolumn{7}{|c|}{ Pretreatment Effect } \\
\hline Control & $148.6 \pm 9.6 \mathrm{a}$ & $141.8 \pm 10.3 \mathrm{a}$ & $5.5 \pm 0.6 \mathrm{~b}$ & $5.1 \pm 1.0 \mathrm{~b}$ & $0.997 \pm 0 \mathrm{a}$ & $31.4 \pm 0.1 \mathrm{a}$ \\
\hline Hot water & $157.5 \pm 3.9 \mathrm{a}$ & $148.9 \pm 10.8 \mathrm{a}$ & $5.7 \pm 0.8 \mathrm{~b}$ & $6.0 \pm 0.7 \mathrm{~b}$ & $0.997 \pm 0 \mathrm{a}$ & $31.7 \pm 2.3 \mathrm{a}$ \\
\hline $6 \% \mathrm{NaOH}$ & $159.6 \pm 26.5 \mathrm{a}$ & $154.5 \pm 20.4 \mathrm{a}$ & $7.6 \pm 0.4 \mathrm{a}$ & $9.8 \pm 1.0 \mathrm{a}$ & $0.996 \pm 0 \mathrm{a}$ & $33.0 \pm 2.4 \mathrm{a}$ \\
\hline LSD & 42.0 & 38.2 & 1.6 & 1.6 & 0.006 & 5.1 \\
\hline
\end{tabular}

Note. ${ }^{1} \&^{2}$ Simulated and experimental biomethane potentials $\left(\mathrm{mL} \mathrm{g}_{\mathrm{vs}}{ }^{-1}\right)$, respectively; ${ }^{3}$ Maximum daily rate of biomethane production; ${ }^{4}$ Lag phase (d); ${ }^{5}$ least significant difference.

Each value is a mean $\pm \mathrm{SD}$ from triplicates. The values across a column sharing the same letter are similar at $\alpha=$ 0.05 .

(a)

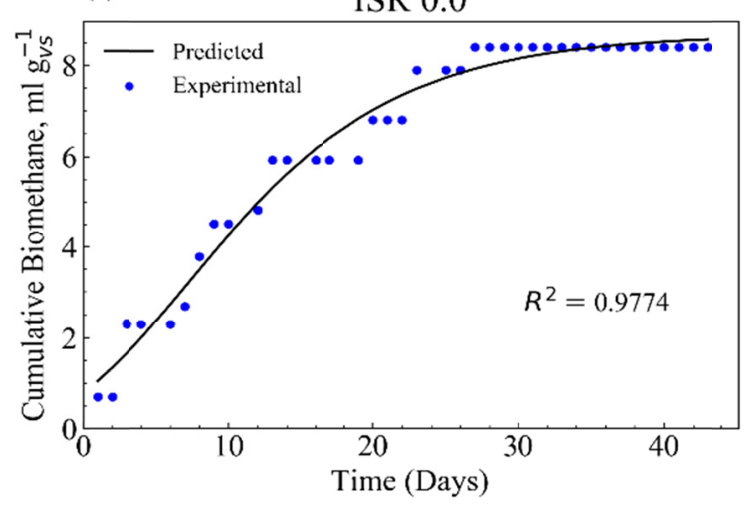

(c)

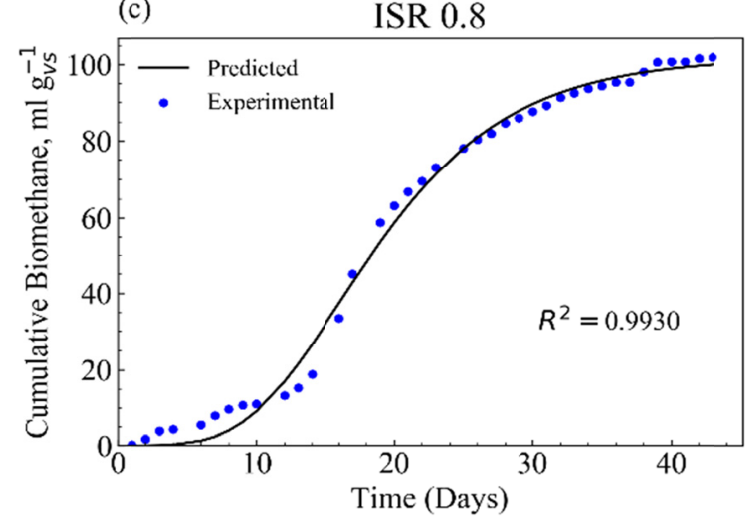

(b)

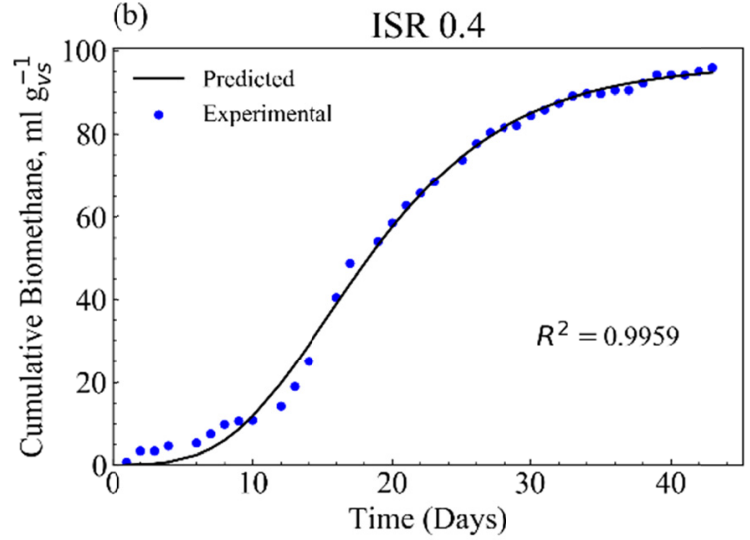

(d)

ISR 1.2

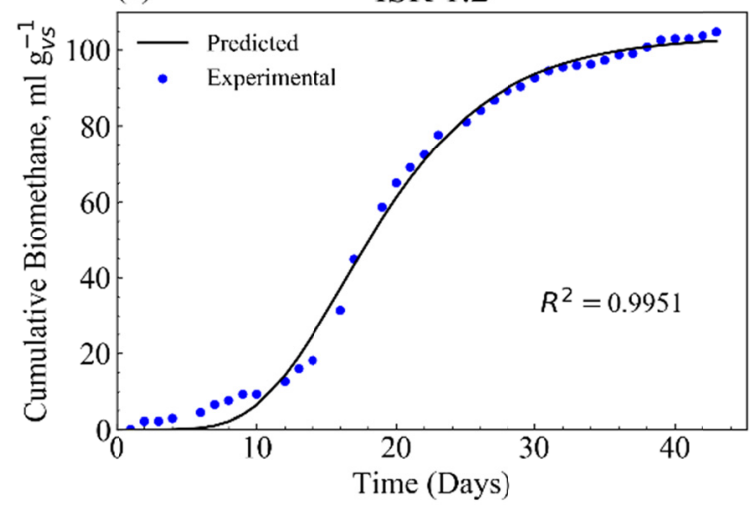


(e)

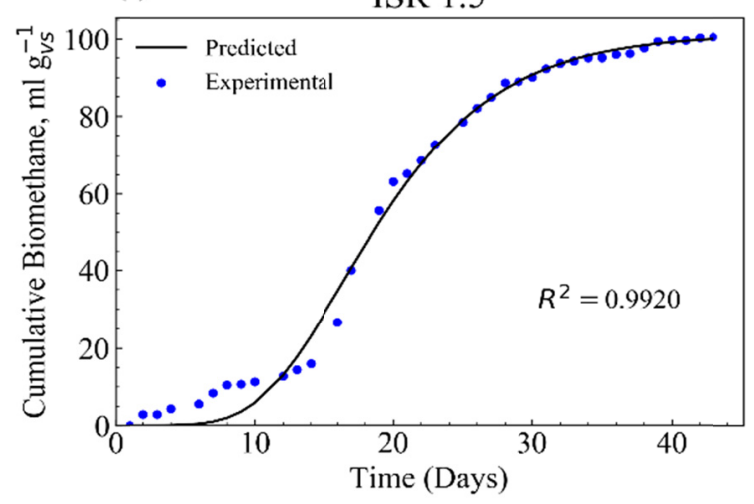

(g)

(f)

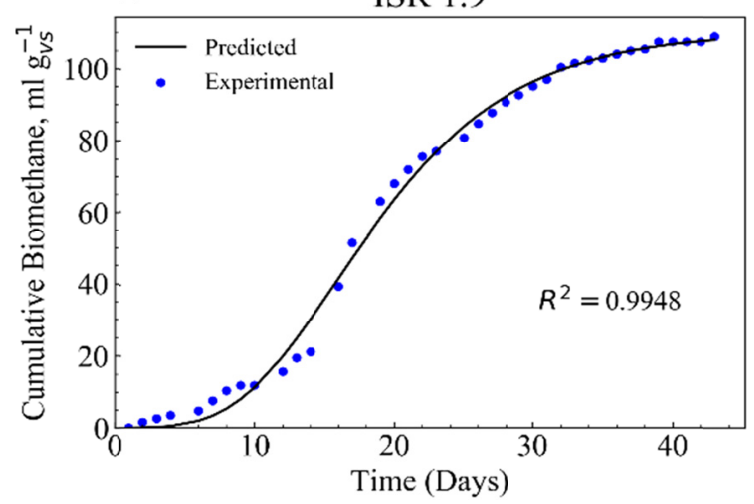

ISR 2.3

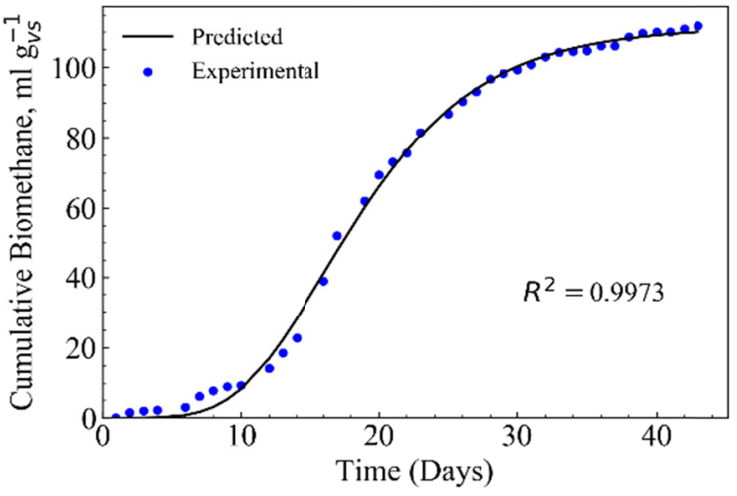

Figure 6. Experimental and predicted cumulative biomethane $\left(\mathrm{mL} \mathrm{g}_{\mathrm{vs}}{ }^{-1}\right)$ at different ISRs

(a)

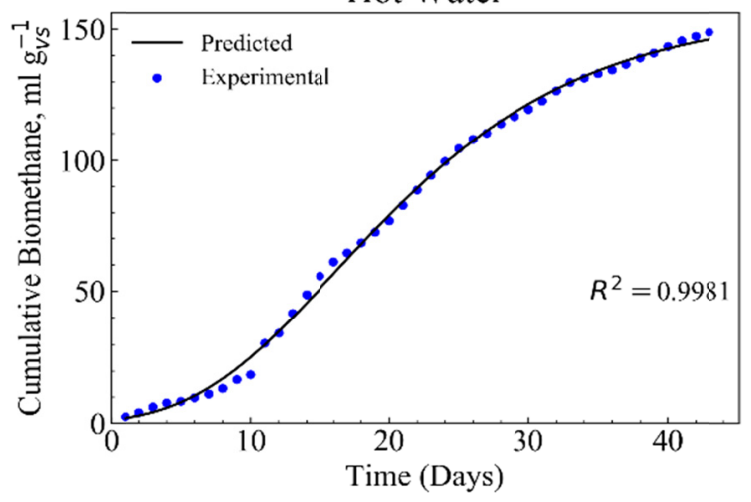

(b)

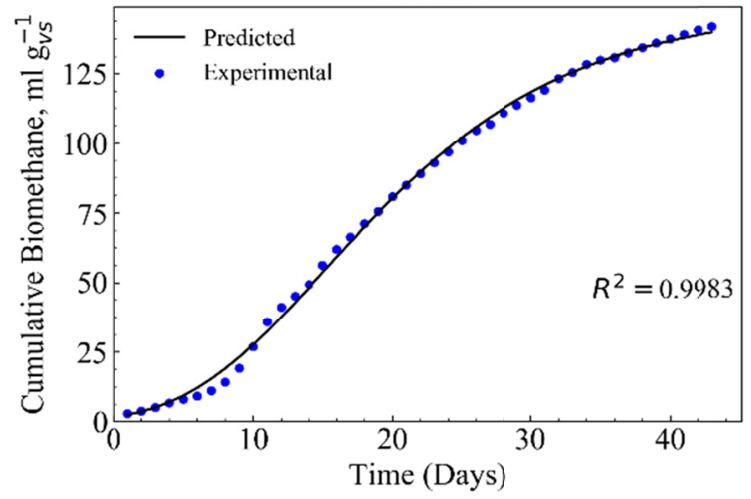

(c)

$6 \% \mathrm{NaOH}$

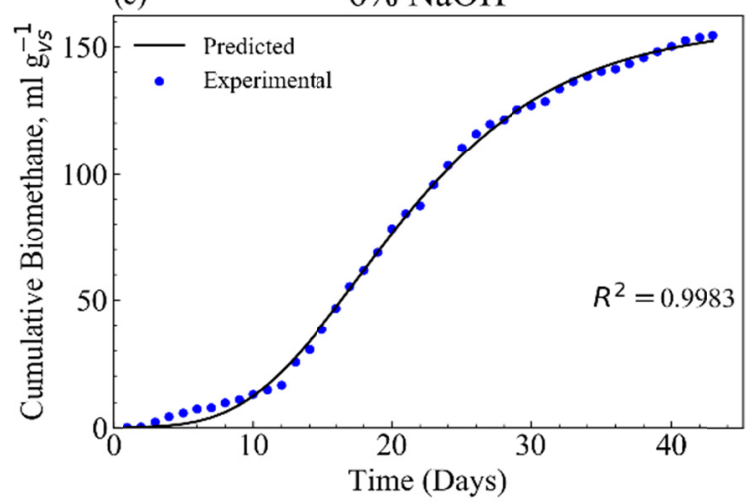

Figure 7. Experimental and predicted cumulative biomethane $\left(\mathrm{mL} \mathrm{g}_{\mathrm{vs}}{ }^{-1}\right)$ in the hot water (a) control (b) and $6 \%$ $\mathrm{NaOH}$ pretreatments 


\subsection{Biodegradability}

Without the addition of inoculum, CGT is hardly degradable, and only $1.8 \pm 0.1 \%$ of the added biomass was recovered as biomethane (Table 2).

In the pretreatment experiment, the BDs of $33.0 \pm 2.4,31.7 \pm 2.3$, and $31.4 \pm 0.1$ were statistically similar in $6 \%$ alkali, the hot water treatments, and control, respectively.

Lignin is one of the most recalcitrant components of the plant-based agro-wastes and is not easily degraded during anaerobic digestion ( $\mathrm{Li}$ et al., 2018). The lignin content of organic manures and energy crops, and animal manures is negatively correlated to their BMP (Kafle \& Chen, 2016; Triolo et al., 2011). The CGT in this study had a lignin content of $32.7 \%$, which on solubilization by alkali might have lead to higher BD (although not significant) in $6 \% \mathrm{NaOH}$ treatment (Hassan et al., 2014). Shi et al. (2009) reported that a combination of fungal and alkali pretreatments in cotton stalks yielded higher biomethane by removing/softening recalcitrant biomass ingredients eg, xylan.

\section{Conclusion}

Our study reveals that for proper digestion of CGT the ISR should be more than 0.4. The pretreatments do not enhance biomethane yield and the modified Gompertz equation fits well with the anaerobic digestion of CGT. The gin trash biodegrades better with an increase in volatile solid loading rate from 1 to $7.9 \%$. The $\mathrm{T}_{80-90}$ for CGT at the ISRs of $1.2,1.5$, and 2.3 was 26-30 days, whereas $\mathrm{T}_{80-90}$ at ISRs of $0.4,0.8$, and 1.9 were 26-31, $27-32$, and 27-31, respectively. The $6 \% \mathrm{NaOH}$ treatment significantly increased the biodegradability of cotton gin waste. These findings further enhance understanding of the underlying factors in the anaerobic digestion of CGT and will facilitate to maximize biomethane recovery from this agro-industrial waste.

\section{Acknowledgements}

This work is supported by the USDA-CBG program grant (Award No. 2018-38821-27750) and partial support by the NSF CREST Center for Energy and Environmental Sustainability (CEES) at Prairie View A\&M University (NSF Award \#1914692), Prairie View, Texas. Dr. Kommalapati would like to thank Dr. Vamsi Botlaguduru, Assistant Professor, IIT Bombay, India, who immensely contributed to this project in the initial stages as a post-doctoral researcher at PVAMU. The contributions of CEES Research Scientist Dr. Hongbo Du are also highly appreciated.

\section{References}

Adl, M., Sheng, K., \& Gharibi, A. (2012). Technical assessment of bioenergy recovery from cotton stalks through the anaerobic digestion process and the effects of inexpensive pretreatments. Applied Energy, 93, 251-260. https://doi.org/10.1016/j.apenergy.2011.11.065

Agblevor, F. A., Batz, S., \& Trumbo, J. (2003). Composition and ethanol production potential of cotton gin residues. Applied Biochemistry and Biotechnology, 105, 219-230. https://doi.org/10.1385/ABAB:105: $1-3: 219$

Angelidaki, I., \& Sanders, W. (2004). Assessment of the anaerobic biodegradability of micropollutants. Reviews in Environmental Science \& Biotechnology, 3, 117-129. https://doi.org/10.1007/s11157-004-2502-3

Angelidaki, I., Alves, M., Bolzonella, D., Borzacconi, L., Campos, J. L., Guwy, A. J., ... Van Lier, J. B. (2009). Defining the biomethane potential (BMP) of solid organic wastes and energy crops: A proposed protocol for batch assays. Water Science \& Technology, 59, 927-934. https://doi.org/10.2166/wst.2009.040

APHA. (2005). Standard methods for the examination of water and wastewater (20th ed.). American Public Health Association, Washington, DC, USA.

Buswell, A., \& Neave, S. (1930). Laboratory studies of sludge digestion. Bulletin. Illinois State Water Survey, 30.

Cheng, X.-Y., \& Zhong, C. (2014). Effects of feed to inoculum ratio, co-digestion, and pretreatment on biogas production from anaerobic digestion of cotton stalk. Energy \& Fuels, 28, 3157-3166. https://doi.org/ $10.1021 / \mathrm{ef} 402562 \mathrm{z}$

Cotton Incorporated. (2020). Monthly Economic Letter: July 2020.

Filer, J., Ding, H. H., \& Chang, S. (2019). Biochemical methane potential (BMP) assay method for anaerobic digestion research. Water, 11, 921. https://doi.org/10.3390/w11050921 
Funk, P. A., Armijo, C. B., Hanson, A. T., Samani, Z. A., Macias-Corral, M. A., Smith, G. B., \& Riordan, J. T. (2005). Converting gin and dairy wastes to methane. Transactions of the American Society of Agricultural Engineering, 48, 1197-1201. https://doi.org/10.13031/2013.18502

Guo, M., Song, W., \& Buhain, J. (2015). Bioenergy and biofuels: History, status, and perspective. Renewable and. Sustainable Energy Reviews, 42, 712-725. https://doi.org/10.1016/j.rser.2014.10.013

Hamawand, I., Sandell, G., Pittaway, P., Chakrabarty, S., Yusaf, T., Chen, G., ... Hopf, J. (2016). Bioenergy from cotton industry wastes: A review and potential. Renewable and Sustainable Energy Reviews, 66, 435-448. https://doi.org/10.1016/j.rser.2016.08.033

Haque, A. N. M. A., Remadevi, R., \& Naebe, M. (2020). A review on cotton gin trash: sustainable commodity for material fabrication. Journal of Cleaner Production, 2020, 125300. https://doi.org/10.1016/j.jclepro. 2020.125300

Hassan, S. S., Williams, G. A., \& Jaiswal, A. K. (2018). Emerging technologies for the pretreatment of lignocellulosic biomass. Bioresource Technology, 262, 310-318. https://oi.org/10.1016/j.biortech. 2018.04.099

Holliger, C., Alves, M., Andrade, D., Angelidaki, I., Astals, S., Baier, U., ... Wierinck, I. (2016). Towards a standardization of biomethane potential tests. Water Science \& Technology, 74, 2515-2522. https://doi.org/ 10.2166/wst.2016.336

Holt, G. A., Blodgett, T. L., \& Nakayama, F. S. (2006). Physical and combustion characteristics of pellet fuel from cotton gin by-products produced by select processing treatments. Industrial Crops and Products, 24(3), 204-213. https://doi.org/10.13031/2013.3036

Isci, A., \& Demirer, G. N. (2007). Biogas production potential from cotton wastes. Renewable Energy, 32, 750-757. https://doi.org/10.1016/j.renene.2006.03.018

Jeoh, T. (1988). Steam explosion pretreatment of cotton gin waste for fuel ethanol production. Virginia Polytechnic Institute and State University.

Jeoh, T., \& Agblevor, F. A. (2001). Characterization and fermentation of steam exploded cotton gin waste. Biomass and Bioenergy, 21, 109-120. https://doi.org/10.1016/S0961-9534(01)00028-9

Jönsson, L. J., \& Martín, C. (2016). Pretreatment of lignocellulose: Formation of inhibitory by-products and strategies for minimizing their effects. Bioresource Technology, 199, 103-112. https://doi.org/10.1016/ j.biortech.2015.10.009

Kafle, G. K., \& Chen, L. (2016). Comparison on batch anaerobic digestion of five different livestock manures and prediction of biochemical methane potential (BMP) using different statistical models. Waste Management, 48, 492-502. https://doi.org/10.1016/j.wasman.2015.10.021

Kafle, G. K., Kim, S. H., \& Sung, K. I. (2013). Ensiling of fish industry waste for biogas production: A lab scale evaluation of biochemical methane potential (BMP) and kinetics. Bioresource Technology, 127, 326-336. https://doi.org/10.1016/j.biortech.2012.09.032

Kim, J. Y., Lee, H. W., Lee, S. M., Jae, J., \& Park, Y. K. (2019). Overview of the recent advances in lignocellulose liquefaction for producing biofuels, bio-based materials and chemicals. Bioresource Technology, 279, 373-384. https://doi.org/10.1016/j.biortech.2019.01.055

Kythreotou, N., Florides, G., \& Tassou, S. A. (2014). A review of simple to scientific models for anaerobic digestion. Renewable Energy, 71, 701-714. https://doi.org/10.1016/j.renene.2014.05.055

Lay, J.-J., Li, Y.-Y., \& Noike, T. (1996). Effect of moisture content and chemical nature on methane fermentation characteristics of municipal solid wastes. Doboku Gakkai Ronbunshu, 1996, 101-108. https://doi.org/2208/ jscej.1996.552_101

Lay, J.-J., Li, Y.-Y., \& Tatsuya, N. (1997). Influences of pH and moisture content on the methane production in high-solids sludge digestion. Water Research, 31, 1518-1524. https://doi.org/10.1016/S0043-1354(96) 00413-7

Li, W., Khalid, H., Zhu, Z., Zhang, R., Liu, G., Chen, C., \& Thorin, E. (2018). Methane production through anaerobic digestion: Participation and digestion characteristics of cellulose, hemicellulose and lignin. Applied Energy, 226, 1219-1228. https://doi.org/10.1016/j.apenergy.2018.05.055 
Maglinao, A. L., Capareda, S. C., \& Nam, H. (2015). Fluidized bed gasification of high tonnage sorghum, cotton gin trash and beef cattle manure: Evaluation of synthesis gas production. Energy Conversion and Management, 105, 578-587. https://doi.org/10.1016/j.enconman.2015.08.005

Meegoda, J. N., Li, B., Patel, K., \& Wang, L. B. (2018). A review of the processes, parameters, and optimization of anaerobic digestion. International Journal of Environmental Research and Public Health, 15, 2224. https://doi.org/10.3390/ijerph15102224

Moody, L., Burns, R., Wu-haan, W., \& Spajic, R. (2009). Use of biochemical methane potential (BMP) assays for predicting and enhancing anaerobic digester performance. Proceedings of the 44th Croatian and the 4th International Symposium on Agriculture, February 16-20, 2009, Opatija, Croatia.

Ohemeng-Ntiamoah, J., \& Datta, T. (2019). Perspectives on variabilities in biomethane potential test parameters and outcomes: A review of studies published between 2007 and 2018. Science of Total Environment, 664, 1052-1062. https://doi.org/10.1016/j.scitotenv.2019.02.088

Pang, Y. Z., Liu, Y. P., Li, X. J., Wang, K. S., \& Yuan, H. R. (2008). Improving biodegradability and biogas production of corn stover through sodium hydroxide solid state pretreatment. Energy \& Fuels, 22, 2761-2766. https://doi.org/10.1021/ef800001n

Raposo, F., Borja, R., Martín, M. A., Martín, A., de la Rubia, M. A., \& Rincón, B. (2009). Influence of inoculum-substrate ratio on the anaerobic digestion of sunflower oil cake in batch mode: Process stability and kinetic evaluation. Chemical Engineering Journal, 149, 70-77. https://doi.org/10.1016/j.cej.2008. 10.001

Raposo, F., Fernández-Cegrí, V., De la Rubia, M. A., Borja, R., Béline, F., Cavinato, C., ... de Wilde, V. (2011). Biochemical methane potential (BMP) of solid organic substrates: Evaluation of anaerobic biodegradability using data from an international interlaboratory study. Journal of Chemical Technology \& Biotechnology, 86, 1088-1098. https://doi.org/10.1002/jctb.2622

Richards, B. K., Cummings, R. J., White, T. E., \& Jewell, W. J. (1991). Methods for kinetic analysis of methane fermentation in high solids biomass digesters. Biomass and Bioenergy, 1, 65-73. https://doi.org/10.1016/ 0961-9534(91)90028-B

Santos, A, Bustamante, M. A., Tortosa, G., Moral, R., \& Bernal, M. P. (2016). Gaseous emissions and process development during composting of pig slurry: The influence of the proportion of cotton gin waste. Journal of Cleaner Production, 112, 81-90. https://doi.org/10.1016/j.jclepro.2015.08.084

Shi, J., Sharma-Shivappa, R. R., Chinn, M., \& Howell, N. (2009). Effect of microbial pretreatment on enzymatic hydrolysis and fermentation of cotton stalks for ethanol production. Biomass and Bioenergy, 33, 88-96. https://doi.org/10.1016/j.biombioe.2008.04.016

Thomasson, J. A. (1990). A review of cotton gin trash disposal and utilization. Proceedings-Beltwide Cotton Production Research Conferences. USDA, ARS, Cotton Ginning Laboratory, Stoneville, MS.

Triolo, J. M., Sommer, S. G., Møller, H. B., Weisbjerg, M. R., \& Jiang, X. Y. (2011). A new algorithm to characterize biodegradability of biomass during anaerobic digestion: Influence of lignin concentration on methane production potential. Bioresource Technology, 102, 9395-9402. https://doi.org/10.1016/j.biortech. 2011.07.026

USEPA. (2019). Livestock anaerobic digester database AgSTAR: Biogas recovery in the agriculture sector. Retrieved from https:/www.epa.gov/agstar/livestock-anaerobic-digester-database

Wilde, C., Johnson, J., \& Farmer, M. (2010). Inventory of cotton gin trash on the Texas high plains and bio-energy feedstock potentials. Texas Journal of Agriculture and Natural Resources, 23, 42-49.

Zhang, Z., Xie, Y., He, X., Li, X., Hu, J., Ruan, Z., \& Liang, Y. (2016). Comparison of high-titer lactic acid fermentation from $\mathrm{NaOH}$ - and $\mathrm{NH}_{3}-\mathrm{H}_{2} \mathrm{O}_{2}$-pretreated corncob by Bacillus coagulans using simultaneous saccharification and fermentation. Scientific Reports, 6, 37245. https://doi.org/10.1038/srep3724

\section{Copyrights}

Copyright for this article is retained by the author(s), with first publication rights granted to the journal.

This is an open-access article distributed under the terms and conditions of the Creative Commons Attribution license (http://creativecommons.org/licenses/by/4.0/). 